7. Reprod. Fert. (1968) 15, 457-459

\title{
DEPLETION OF RAT OVARIAN ASCORBIC ACID BY A FACTOR OTHER THAN LUTEINIZING HORMONE PRESENT IN THE BLOOD OF THE PIG
}

\author{
D. B. CRIGHTON \\ Department of Physiology and Environmental Studies, \\ University of Nottingham, School of Agriculture, \\ Sutton Bonington, Loughborough, Leics.
}

(Received 8th December 1967)

The ovarian ascorbic acid depletion (OAAD) assay of Parlow (1958) is an established method for the measurement of luteinizing hormone $(\mathbf{L H})$. Tests using purified preparations of other anterior pituitary hormones have shown the bio-assay to be specific for LH (McCann \& Taleisnik, 1960; Schmidt-Elmendorff \& Loraine, 1962) but vasopressin possesses appreciable activity (McCann \& Taleisnik, 1960). Pelletier (1964) has reported that hypophysectomized ewe plasma caused a significant response when assayed by this method. Evidence has been produced suggesting that the plasma acted by releasing LH from the pituitary glands of the assay rats (Pelletier, 1965).

Recently, determinations of the pituitary content of LH in the sow at various reproductive stages and after ovariectomy have been carried out in this laboratory. A preliminary report of this work has already been presented (Crighton, 1967). In the course of this work, serum was obtained from the jugular venous effluent at the slaughter of each sow.

After storage for variable periods at $-20^{\circ} \mathrm{C}$ the samples of serum were tested individually and concurrently for LH activity using the OAAD method. The procedure used was a modification of that described by Schmidt-Elmendorff \& Loraine (1962). Each rat was anaesthetized with an intraperitoneal injection of sodium pentobarbitone (Veterinary Nembutal Solution, Abbott Laboratories Ltd). One ovary was then removed using the dorsal approach. The test sample was immediately injected into the femoral vein. Each rat was killed $1 \mathrm{hr} \pm 3$ min after injection and the second ovary was removed. Each sample of serum was injected into six rats, each rat receiving a volume of $2.0 \mathrm{ml}$. In addition, ten rats were each injected with $2.0 \mathrm{ml}$ of $0.9 \% \mathrm{NaCl}$. The ascorbic acid concentrations of the two ovaries were then determined and the results were expressed as the percentage OAAD produced in the treated ovary (removed at autopsy) compared with the control ovary (removed before injection). The mean percentage OAAD for each sample was calculated. The significance of the depletion produced by each sample of serum was tested using the ' $t$ '-test and the signifi- 
cance of the differences between the groups in their ability to produce OAAD was tested by analysis of variance. The groups of sows and the group mean results are shown in Table 1.

TABLE 1

OAAD PRODUCED BY SERUM OF EXPERIMENTAL SOWS

\begin{tabular}{|c|c|c|c|}
\hline Group & No. of sows & $\begin{array}{l}\text { Reproductive status } \\
\text { at slaughter }\end{array}$ & $\begin{array}{c}\text { Mean } O A A D \\
\text { produced by } \\
2 \cdot 0 \text { ml serum } \\
(\% \pm S . E .)\end{array}$ \\
\hline 1 & 3 & $\begin{array}{c}\text { Lactating } 45 \text { to } 46 \text { days, } \\
\text { anoestrous }\end{array}$ & $44 \cdot 8 \pm 3 \cdot 6$ \\
\hline 2 & 3 & $\begin{array}{c}\text { Lactating } 45 \text { to } 46 \text { days, } \\
\text { ovariectomized } 25 \text { days } \\
\text { previously }\end{array}$ & $48 \cdot 9+10 \cdot 4$ \\
\hline 3 & 4 & $\begin{array}{l}\text { Cycling, Day } 5 \text { of } \\
\text { oestrous cycle }\end{array}$ & $48 \cdot 1 \pm 2 \cdot 0$ \\
\hline 4 & 4 & $\begin{array}{l}\text { Ovariectomized } 25 \text { days } \\
\text { previously on Day } 5 \\
\text { of oestrous cycle }\end{array}$ & $50 \cdot 8 \pm 5 \cdot 2$ \\
\hline
\end{tabular}

The injection of isotonic saline produced a non-significant increase in ovarian ascorbic acid of $1.1 \%$. All samples of serum produced significant OAAD $(P<0.001$ in each case). There were no significant differences between the groups in the mean depletions produced.

It seemed obvious that the depletions did not represent the levels of $\mathrm{LH}$ present in the blood of the sows in life. In order to determine whether the observed depletions were due to $\mathrm{LH}$ or to some other factor, two experiments were designed.

TABle 2

OAAD PRODUGED BY PURIFIED LH AND SOW SERUM INCUBATED IN THE PRESENCE AND ABSENCE OF 6 M-UREA

\begin{tabular}{l|c}
\hline \multicolumn{1}{c|}{ Sample } & $\begin{array}{c}\text { Mean } O A A D \\
\text { produced by } 1 \cdot 0 \mathrm{ml} \\
\text { solution }(\% \pm S . E .)\end{array}$ \\
\hline NIH-LH & $29 \cdot 0 \pm 3 \cdot 3$ \\
NIH-LH + urea & $13 \cdot 0 \pm 3 \cdot 6$ \\
Serum & $29 \cdot 4 \pm 3 \cdot 6$ \\
Serum + urea & $30 \cdot 0 \pm 2 \cdot 2$ \\
\hline
\end{tabular}

In the first experiment, a sample of sow serum previously demonstrated to produce OAAD was incubated under suitable conditions with 6 M-urea. Such incubation has been shown to destroy the LH activity of purified preparations of $\mathrm{LH}$ alone and when present as a component in a mixture of other gonadotrophic hormones and the LH activity of such preparations as Pergonal, PMSG and HGG (Ellis, 1961; Schmidt-Elmendorff, Loraine \& Bell, 1962). The effect of $6 \mathrm{M}$-urea on sow serum was compared with its effects on a purified preparation of LH (NIH-LH-s9; National Institutes of Health, U.S.A.). 
Before this experiment, preliminary investigations were carried out in order to determine doses of serum and NIH-LH required to produce comparable depletions. The purified preparation of $\mathbf{L H}$ was dissolved in $0.9 \% \mathrm{NaCl}$ to provide a concentration of $10.0 \mu \mathrm{g} / \mathrm{ml}$. Two $25.0 \mathrm{ml}$ aliquots of this solution were taken and urea added to one to provide a concentration of 6 м. Similarly, two $25 \cdot 0-\mathrm{ml}$ aliquots of serum were taken and urea was added to one to provide a concentration of $6 \mathrm{~m}$. All four samples were incubated in $100 \mathrm{ml}$ conical flasks in a water bath at $40 \pm 1^{\circ} \mathrm{C}$ for $24 \mathrm{hr}$. After incubation the samples were dialysed against $0.9 \% \mathrm{NaCl}$ at $3^{\circ} \mathrm{C}$ for $24 \mathrm{hr}$. They were then assayed using the method as before, $1.0 \mathrm{ml}$ of solution being injected into each rat and ten rats being used for each sample. The results are shown in Table 2. The incubation of purified $\mathrm{LH}$ with $6 \mathrm{M}$-urea resulted in a significant decrease $(P<0 \cdot 01)$ in the OAAD produced, whereas similar treatment of sow serum did not affect its activity.

For the second of these experiments, a sample of hypophysectomized gilt plasma was obtained. The plasma was transported from the U.S.A. in the frozen state and was stored at $-20^{\circ} \mathrm{C}$ until required for assay. The assay method was as described previously. The dosage per rat of the gilt plasma was $1.0 \mathrm{ml}$. Two replicates of the experiment were carried out, using ten rats in each. In both replicates of the experiment, the plasma produced a significant OAAD $(P<0.01$ in both cases $)$. The mean percentage depletions with S.E. produced were $25 \cdot 1 \pm 3 \cdot 6$ and $24 \cdot 1 \pm 5 \cdot 0$ in the first and second replicates respectively.

The results of these experiments provide evidence that the OAAD produced by the serum of the experimental sows was not due to LH or to any other hormone of pituitary origin. They demonstrate that the OAAD method is unsuitable for the assay of the unextracted serum or plasma of the pig and hence agree with the results of Pelletier (1964) in the sheep.

I wish to thank Professor R. M. Melampy, University of Iowa, Ames, Iowa, U.S.A., for the sample of hypophysectomized gilt plasma. Part of the expenses of this work was borne by the Pig Industry Development Authority. Hormone preparations used were gifts from the National Institutes of Health, U.S.A., Burroughs Wellcome and Co. and Organon Ltd.

\section{REFERENCES}

Grighton, D. B. (1967) Effects of lactation on the pituitary gonadotrophins of the sow. In: University of Nottingham 13th Easter Symposium: Reproduction in the Female Mammal, p. 223. Eds. G. E. Lamming and E. C. Amoroso. Butterworths, London.

ElLIS, S. (1961) Bioassay of luteinizing hormone. Endocrinology, 68, 334.

MCCANN, S. M. \& TALEISNIK, S. (1960) Effect of luteinizing hormone and vasopressin on ovarian ascorbic acid. Am. F. Physiol. 199, 847.

Parlow, A. F. (1958) A rapid bioassay method for LH and factors stimulating LH secretion. Fedn Proc. Fedn Am. Socs exp. Biol. 17, 402 .

Pelletier, J. (1964) Dosage de l'hormone stimulant l'interstitielle (ICSH) dans le sang par la méthode de l'acide ascorbique ovarien. C.r. hebd. Séanc. Acad. Sci., Paris, 258, 5979.

Pelletier, J. (1965) Effet du plasma de brebis sur la décharge de LH chez la ratte. C.r. hebd. Séanc. Acad. Sci., Paris, 260, 5624.

Schmidt-Elmendorff, H. \& Loraine, J. A. (1962) Some observations on the ovarian ascorbic acid depletion method as a test for luteinizing hormone activity. 7 . Endocr. 23, 413 .

Schmidt-ElmendorfF, H., Loraine, J. A. \& Beld, E. T. (1962) The effect of 6 m urea on the follicle stimulating and luteinizing hormone activities of various gonadotrophin preparations. $\mathcal{F}$. Endocr. 24, 153. 